\title{
Microbial Pigments: Natural Colorants and their Industrial Applications
}

\author{
Hrucha Vaidya, Nishigandha Upasani and Padmini S. Wagh* \\ Department of Biotechnology, KTHM College, Nashik, Maharashtra, India \\ *Corresponding author
}

\section{Keywords}

Microbial Pigments, characterization, synthetic colorants, non toxic, applications

Article Info

\section{Accepted:}

20 April 2021

Available Online:

10 May 2021

\section{A B S T R A C T}

Pigments are the chemical substances that absorb the light of visible region. Pigments are compounds that are widely used in industries. Non-toxic nature of pigment produced by a number of microorganisms make them ecofriendly for utilization in dye, foodstuff, pharmaceutical, cosmetics and other industrial purpose. Industrial production of natural food colorants by microbial fermentation has several advantages such as cheaper production, easier extraction, higher yields through strain improvements, no lack of raw materials and season independent. With the increasing awareness about toxic effects of synthetic colors and consumers safety, there is increasing interest in the development of colors from the microbial sources. This research is concerned with reducing hazardous impact of synthetic colorants by microbial pigment applications. For this purpose various pigment producing bacteria were isolated, characterized and identified. Efficient microbial pigment producing strains were used for pigment production. Various pigments were extracted and their applications were studied by using different techniques.

\section{Introduction}

Pigments are compounds which have characteristics of importance to many industries. In the food industry they are used as additives, color intensifiers, antioxidants, etc. Pigments come in a wide variety of colors, some of which are water soluble. The production of colorant from biological agents for food and textile has increased interest in recent years. Nature produces many bio colorants from various resources including plants and microorganisms, which are possible alternatives to synthetic dyes and pigments currently employed. The recent awareness in human safety and environmental conservation has made fresh enthusiasm for natural sources of colors. Natural colorants or dyes derived from flora and fauna are believed to be safe because of non-toxic, non-carcinogenic, 
ecofriendly and biodegradable in nature. As the present trend throughout the world is shifting towards the use of ecofriendly and biodegradable commodities, the demand for natural colorants is increasing day by day. Due to strong consumers demand for natural products. There has been much interest in the development of new natural colorants for use in the different industries. Natural pigments are sourced from ores, insects, plants and microbes. Bio pigments produced from microorganisms are preferred over those from plants because of their stability and availability for cultivation throughout the year. Among microbes, bacteria have immense potential to produce diverse bioproducts and one such bioproduct is pigment. The production and applications of microbial pigments as natural colorants has been investigated by various researchers.

Microbial pigment production is now one of the emerging field of research to demonstrate its potential of various industrial applications. Most of the microbial pigments production is still in the R\&D stage. Hence, work on the bacterial pigments should be intensified especially in finding cheap and suitable growth medium which can reduce the cost and increase its applicability for industrial production. The utilization of natural pigments in foodstuff, dyestuff, cosmetics and pharmaceutical manufacturing processes has increased in the recent years due to their nontoxic nature. Moreover, their eco-friendly, antioxidant, anticancer and antimicrobial activities further add positive effects. The significant growth in the naturally derived colors has been attributed to their stability and consumer perception. Further the annual growth rate of 3-5 percent. There is growing interest in microbial pigments due to their natural character and safe to use, medicinal properties, nutrients like vitamins, production being independent of season and geographical conditions, controllable and predictable yield.
Bacterial pigments can be produced from waste materials thus environmental pollution can be reduced.

These pigments have been subjected to a lot of research not only for their colorful nature, but also because they play important roles in photosynthesis, photo protection, pathogenesis etc. Yet other pigments are interesting because of their functional role is unclear.

Color is the most vital attribute of any article particularly food. Biocolor word consists of two words bio and color that means something natural used for purpose. Hence, biocolorants can be one of the alternatives to artificial color for addition into any food material. These are basically those coloring agents, which are obtained from the biological sources for natural pigments such as plants, animals and microbes. These natural colors are generally extracted from fruits, vegetables, seeds, roots and microorganisms and are often called as "biocolors" due to their biological origin. During recent years, pigments extracted from natural sources are highly in demand as natural food coloring agents. Being natural they can replace the synthetic dyes. Since, an artificial color additive tends to impart undesirable taste, negative health issues related to the consumption such as allergenic and intolerance reactions. Food with good texture, nutrients and flavor should be of appealing color then only it can be desirable for human consumption. The demand for natural sources of such compounds is increasing day by day as a result of awareness of positive health benefits out of natural compounds. Currently, the search is also for pigments produced by microorganisms and used commercially as food colorants.

In recent years, search for microorganisms producing nontoxic metabolites has been performed by several researchers. Further, the waste generated from food industry can also 
be one of the substrate for growth of these biocolors producing microorganisms. As the food industry normally, generates a large quantity of waste like peel, seed, pomace, rags kernels, etc. which are biodegradable in nature and can be used as a substrate for growth of these microorganisms.

The waste generated is a rich in carbohydrates, minerals, proteins, and dietary fibers and hence a good source of nutrients for microbial growth. Usage of food industry waste can also help to deal with problems like environmental pollution.

\section{Applications of biocolors}

Biocolors have wide applications as colorants in pharma, food, textile, paper, printing, cosmetic industries etc.

\section{Pharmaceutical industry}

Investigation of most of the microorganisms has shown the efficiency in potential clinical applications of secondary metabolites (pigments) for treating various disease. These have many properties like antibiotic, anticancer, and immunosuppressive properties. The property of bacteria to produce biopigments, is used to produce medically important products. Adonirubinand Astaxanthin are the xanthophylls, which are also acts as a neutraceuticals. These xanthophylls by the process of antioxidation, anti-free radical or other mechanisms help to prevent carcinogenesis. The function of these xanthophylls and carotenes also help to prevent problems like heart attacks and strokes. A red pigment, Astaxanthin is an important carotenoids which has great commercial value, and is also used as pharmaceutical feed. Prodiogiosin is also one of the pigment which can be use for the treatment of the diabetes. It is also a strong therapeutic molecule known for immune suppressive, anticancer properties. Further, the Monascus puepureus produce pigment which help in the inhibition of hepatitis virus replication by interfering with viral RNA polymerase activity. Hahella chejuensis produces a pigment which has the properties of immune suppression and anti-tumor activity.

\section{Dairy industry}

Monascus species are known to produce nontoxic pigment, which can be used as food colorants, flavor enhancer and as a food preservative. Monascus ruber is used to prepare flavored milk by utilizing rice carbohydrate for its metabolism and produces pigment as a secondary metabolite. The solid state fermentation of rice produces red, orange, and yellow colored pigments.

\section{Textile industry}

The textile industry produces large amount of waste which is mainly consist of synthetic dyes. These synthetic dyes are used in industries due to their easy and cheap synthesis, stability towards light, temperature and advanced colors covering whole color spectrum. However, these synthetic dyes have many drawbacks like toxicity, mutagenicity, and carcinogenicity which are leading to various health problems which are much more severe like skin cancer and some allergies. Hence, consumers demand for dyes of natural origin as colorants.

\section{Nutritional supplements}

Chemical compounds in the biocolor are produced by plant cells known as vegetal active principles. These compounds are the means for obtaining biological active substances and many other natural compounds which are used in foods, pharmaceuticals and cosmetic industries with having high 
commercial value. As $\beta$-carotene is the precursor of vitamin A, so carotenoids can be used as a vitamin supplements. Rice is the main food in under developed countries, so there is possibility of deficiency of vitamin A which causes night blindness and in serious cases to xerophthalmia.

Another example of natural food grade biocolorants is Riboflavin which is also a source of vitamins, available in milk, several leafy vegetables, meat and fish. Yellow $\beta$ xanthins are used as biocolorants and can also be used for introducing essential dietary amino acids into food stuffs.

\section{Printing industry}

To conserve the forest resources and reduction of wastes it's important to reuse and recycle papers in offices etc. The reuse of papers is important but it's also important to disappear the prints from paper. Decolorable ink contains Monascus pigments used for inkjet printing. These pigments from Monascus when exposed to irradiation of visible or ultraviolet light get discolored. Food colorants: An important goal of food industry is to produce food with an attractive appearance. Food producers are opting for natural food colors, as artificial ones shows many negative impacts on human health when it gets consumed. Demand for natural food colors are available, in which microbial colorants play important role as food coloring agent as its production and down streaming is easy.

Penicillium oxalicum is a fungus which produces red color used in cosmetic and food industry. These colors are useful in different products like baby foods, breakfast cereals, pastas, sauces, processed cheese, fruit drinks, vitamin-enriched milk products, and some energy drinks and so on. Therefore, natural colors are environment friendly and moreover serve as the dual need for visually attractive colors and health benefits in food colorants of probiotic. Therefore, pigments from microbial sources are good alternative. The addition of natural or microbial colors in food products can also help to overcome the growing public concern over the adverse effects. In addition, natural colorants will not only be beneficial to human health but will also be helpful for the maintenance of biodiversity.

\section{Materials and Methods}

\section{Sample Collection}

Soil and water samples were collected from different sites of Nashik, Maharashtra. By performing serial dilutions samples were diluted. Samples were streaked on nutrient agar plate and kept for incubation at $37^{\circ} \mathrm{C}$. After a few days pigmented colonies were obtained (January-February, 2017) (Goswami, et al., 2014)

\section{Screening, Characterization and Identification}

Screening, Characterization and Identification of microorganism is used to find out the distinguishing characteristics among all different types of bacteria. Species identification of similar genus is identified by performing various biochemical tests ( $S$. Samyuktha et al., 2016). Microorganisms are identified by morphological and biochemical tests (Vora, et al., 2014). The results were compared on the basis of Bergey's manual to identify genus and species of isolated organism.

\section{Spectrophotometric Analysis of Pigments}

Spectrophotometric analysis for finding maximum absorbance $\left(\lambda_{\max }\right)$ of pigments using different wavelengths of visible range (Sebnem, et al., 2008). 


\section{Biosafety studies}

\section{Cytotoxicity testing by trypan blue assay}

The goat liver cells were crushed in mortar and pestle with Phosphate Buffer Saline (PBS) and filtered using 4 layered cheesed cloth. Mix $25 \mu \mathrm{l}$ of the pigment sample and $50 \mu \mathrm{l}$ of filtered liver cells with $50 \mu \mathrm{l} 0.25 \%$ solution of trypan blue in PBS. Incubate the sample for 1 hour at room temperature. Count the cells with the help of haemocytometer counter and determine the number of viable cells (cells with a clear cytoplasm) and nonviable cells (cells with a blue cytoplasm) (Ariffin et al., 2010; Hadzir et al., 2014; Shahrul Hisham et al., 2016; Strober 2001).

\section{Probiotic test}

YAKULT containing Lactobacillus casei strain was inoculated on nutrient agar plate by spread plate technique. Pigment suspension was prepared by dissolving the pigmented colonies in sterile $1 \mathrm{ml}$ of saline. The sterile discs of Whatman's filter paper were deeped into the suspension and inoculated on the plate. Plates were incubated at $37^{\circ} \mathrm{C}$ in incubator for 24 hours and check out for halo zones around the discs.

\section{Antimicrobial activity}

Disc diffusion method was done by standard procedure as well diffusion method. Pigment suspension was prepared by dissolving the pigmented colonies in sterile $1 \mathrm{ml}$ of saline. The sterile discs of Whatman's filter paper were deeped into the suspension and inoculated on the plate. Plates were incubated at $37^{\circ} \mathrm{C}$ in incubator for 24 hours and check out for hollow zone around the disc.

Antimicrobial activity of the pigments was tested by disc diffusion method. Three human pathogens (Pseudomonas aeruginosa, E.coli and Staphylococcus aureus) were used against extracted pigment to evaluate its antimicrobial activity.

\section{Extraction of pigments}

\section{Fruit Waste Extract}

The organisms were preserved on the slants for further use. Fruit waste extract was made with the fruit peels of pomegranate, orange and pineapple (Tarangini Korumilli, June2014). Firstly, the all fruit peels are boiled for 30 mins in water bath.

Then it was crushed with the help of mortar and pestle. After crushing all the fruit peels, obtained solution or extract was filtered through the filter paper for clear extract. Then $30 \mathrm{ml}$ of fruit extract was poured into 4 clean culture bottles. In this fruit waste extract $1 \mathrm{ml}$ of suspension inoculated into each bottle. All the bottles were incubated at $37^{\circ} \mathrm{C}$ for $8-10$ days. After 8-10 days, result was observed.

\section{Rice powder Extract}

Rice was soaked for overnight in water (Tarangini Korumilli, June-2014). After soaking, next day rice was grind to make fine powder of it. This fine powder was weighed. Then $5 \mathrm{gm}$ of powder was added to 4 clean culture bottles. Then add $20 \mathrm{ml}$ of the distilled water into each bottle and mix it well. After that $2 \mathrm{ml}$ of suspension of pigmented bacteria was inoculated into each individual bottle. All bottles were kept in incubator at $37^{\circ} \mathrm{C}$ for $8-10$ days. After 8-10 days, results were observed.

\section{Purification of Pigments}

The organisms producing pigments were grown into nutrient broth for $48 \mathrm{hrs}$. For the purpose of purification, Methanol and Ethanol these two solvents were used. For Methanolic extract directly broth is used and for the 
ethanolic extract Rice powder extract sample was used.

\section{Thin Layer Chromatography}

The TLC plate was taken and with a pencil, a thin mark is made at the bottom of the plate to apply the sample spots. Two extracted samples (by using ethanol and methanol) were applied on the spots marked on the line at equal distances. The mobile phase Chloroform: Methanol (1:2) is poured into the TLC chamber separately to a leveled few centimeters above the chamber bottom.

Now, the plate prepared with sample spotting is placed in TLC chamber so that the side of the plate with the sample line is facing the mobile phase. Then the chamber is closed with a lid. The plate is then immersed, such that the sample spots are well above the level of mobile phase (but not immersed in the solvent - as shown in the picture) for development. Allow sufficient time for the development of spots. Then remove the plates and allow them to dry. Observed the spots and calculate Rf value. Rf value is the "Retardation Factor", which is the ratio of the distance traveled by a compound in a mobile phase compared with the distance traveled by the front of the mobile phase itself. It is always greater than or equal to zero, and less than or equal to one.

\section{FTIR (Fourier Transform Infra-Red Spectroscopy)}

FTIR relies on the fact that the most molecules absorb light in the infra-red region of the electromagnetic spectrum. This absorption corresponds specifically to the bonds present in the molecule. The frequency ranges are measured as wave numbers typically over the range $400-600 \mathrm{~nm}^{-1}$.

The background emission spectrum of the IR source is first recorded, followed by the emission spectrum of the IR source with the sample in place. The ratio of the sample spectrum to the background spectrum is directly related to the sample's absorption spectrum. The resultant absorption spectrum from the bond natural vibration frequencies indicates the presence of various chemical bonds and functional groups present in the sample. FTIR is particularly useful for identification of organic molecular groups and compounds due to the range of functional groups, side chains and cross-links involved, all of which will have characteristic vibrational frequencies in the infra-red range.

\section{Applications of Pigments}

Obtained pigments are used as a natural colorants for cloth, cotton, thread, paper, nail paint, lip balm, candles, hair belt, hair rubber etc. (Venil C. K., et al., July 2013) (Suryawanshi T, et al., January 2017).

\section{Results and Discussion}

\section{Sample Collection}

Blue, Yellow, Orange and Pink-red color pigmented colonies were observed.

\section{Screening, Characterization and Identification}

Biochemical identification (S. Samyuktha et.al. 2016) gave results that blue color (Pyocyanin) pigment might be given by an organism Pseudomonas aeruginosa,(Divya Jose, et al.,2018), Orange color (Asthaxanthin) pigment might be given by an organism Brevibacterium linens, Yellow color (Zeaxanthin) pigment might be given by an organism Paracoccus zeaxanthifaciens, and Pink-red color (Canthaxanthin) pigment might be given by an organism Monascus roseus (Francielo Vendruscolo, et al., October 2015)according to bergey's manual. 


\section{Biosafety studies}

\section{Cytotoxicity Test}

There was slight difference in viability of cells with pigment and without pigment. Therefore the pigments were safe for animal cells and does not showed negative effect on eukaryotic cells. Cytotoxicity Test especially trypan blue exclusion test for cell viability was firstly performed by W. Strober in 2001.

\section{Probiotic test}

Probiotic test was discovered by Elie Metchnikoff in year 1907 for which he received Nobel Prize. Probiotic test by using Lactobacillus casei strain was successfully performed. Positive results showed by Orange and Pink-red pigment, thus, these cannot be used as food colorants but they can be used in Textile, Paper, Cosmetic and in other industries. Blue and Yellow color pigment showed negative probiotic test. Thus, these pigments can be used in Textile, Paper, Cosmetic and in other industries along with food industry.

\section{Antimicrobial activity}

Antimicrobial activity against human pathogens (Pseudomonas aeruginosa, E.coli and Staphylococcus aureus) was successfully performed. Positive results conclude that the pigmented organism showed inhibitory action against human pathogens. Those organisms might be use in pharmaceutical industry

\section{Extraction of pigments}

\section{Fruit Waste Extract}

Initial color of fruit waste extract was pale yellow. After inoculation and incubation, color development was not observed but extract was turbid. So that, fruit waste extract is not the suitable extraction medium for the extraction of the pigments.

\section{Rice powder Extract}

Color development was observed clearly on rice powder extract after 8-10 days. Orange color pigment shows prominent color on rice powder extract. So that, Rice powder extract is best and suitable extraction medium for extraction of pigments.

Due to climatic conditions, Yellow color pigment was not showed growth in broth. Hence, it couldn't use for the extraction. Extraction of Blue, Orange and Pink-red colored pigment were carried out successfully.

\section{Purification of Pigments}

Purification of Blue, Orange and Pink-red colored pigments was carried out by using Methanol and Ethanol as solvents. Amount of purified pigment was compared with methanolic and ethanolic extracted dry mass.

Maximum amount of purified dry mass was observed in ethanolic extraction. Therefore, ethanol is the best solvent for purification of pigments.

\section{Thin Layer Chromatography}

TLC of pigments were successfully carried out. Single spot of each pigment was observed on TLC plate. Rf value of each pigment was calculated and are as follows:

For the purpose of FTIR analysis, ethanolic extracted samples were used and they give satisfactory results. Due to environmental conditions yellow colored pigment was not obtained because of that FTIR analysis of yellow pigment could not possible. 


\section{Morphological characteristics}

Table.1 Morphological Characteristics of obtained Pigmented colonies of Microorganisms

\begin{tabular}{|c|c|c|c|c|c|c|c|}
\hline $\begin{array}{c}\text { Sr. } \\
\text { No. }\end{array}$ & Color & Size & Shape & Margin & 0pacity & Texture & Elevation \\
\hline 1 & Blue & $2 \mathrm{~mm}$ & circular & entire & opaque & smooth & convex \\
\hline 2 & Orange & $4 \mathrm{~mm}$ & circular & entire & opaque & smooth & convex \\
\hline 3 & Yellow & $5 \mathrm{~mm}$ & circular & entire & opaque & smooth & convex \\
\hline 4 & Pink red & $1 \mathrm{~mm}$ & circular & entire & opaque & smooth & convex \\
\hline
\end{tabular}

\section{Biochemical Test}

Table.2 Biochemical tests of obtained Pigmented Microorganisms

\begin{tabular}{|c|c|c|c|c|}
\hline Test & $\begin{array}{c}\text { Blue colored } \\
\text { pigmented } \\
\text { culture }\end{array}$ & $\begin{array}{c}\text { Orange } \\
\text { colored } \\
\text { pigmented } \\
\text { culture }\end{array}$ & $\begin{array}{c}\text { Yellow } \\
\text { colored } \\
\text { pigmented } \\
\text { culture }\end{array}$ & $\begin{array}{c}\text { Pink red } \\
\text { colored } \\
\text { pigmented } \\
\text { culture }\end{array}$ \\
\hline Gram Staining & $\begin{array}{c}\text { Gram +ve } \\
\text { rods }\end{array}$ & $\begin{array}{c}\text { Gram +ve } \\
\text { rods }\end{array}$ & $\begin{array}{c}\text { Gram -ve } \\
\text { cocci }\end{array}$ & $\begin{array}{c}\text { Gram -ve } \\
\text { cocci }\end{array}$ \\
\hline Catalase test & - & + & + & - \\
\hline Oxidase test & + & + & + & + \\
\hline $\begin{array}{l}\text { Sugar Fermentation } \\
\text { : }\end{array}$ & - & - & + & + \\
\hline 1. Glucose & - & - & + & - \\
\hline 2. Sucrose & - & - & + & - \\
\hline 3. Fructose & - & - & + & - \\
\hline 4. Xylose & - & - & + & + \\
\hline 5. Mannitol & - & + & + & + \\
\hline $\begin{array}{l}\text { Gelatin hydrolysis } \\
\text { test }\end{array}$ & + & + & + & + \\
\hline $\begin{array}{l}\text { Triple Sugarion } \\
\text { Agar Slant }\end{array}$ & - & - & - & + \\
\hline Starch AgarPlate \\
Test
\end{tabular}


Table.3 Cytotoxic analysis of obtained pigments against animal cells

\begin{tabular}{|c|c|c|c|c|c|}
\hline Sample & $\begin{array}{c}\text { Liver } \\
\text { Cells }\end{array}$ & $\begin{array}{c}\text { Dead } \\
\text { Cells }\end{array}$ & Total Cells & $\begin{array}{c}\% \\
\text { Viability }\end{array}$ & $\begin{array}{c}\text { Conc. Of } \\
\text { cells/ml }\end{array}$ \\
\hline $\begin{array}{c}\text { Cells (Before } \\
\text { incubation) }\end{array}$ & 750 & 10 & 760 & 98.63 & $1.97 \times 10^{6}$ \\
\hline $\begin{array}{c}\text { Cells (After } \\
\text { incubation) }\end{array}$ & 683 & 55 & 735 & 92.92 & $1.85 \times 10^{6}$ \\
\hline $\begin{array}{c}\text { Cells + Blue } \\
\text { Pigment }\end{array}$ & 720 & 59 & 771 & 92.42 & $1.84 \times 10^{6}$ \\
\hline $\begin{array}{c}\text { Cells + } \\
\text { Orange } \\
\text { Pigment }\end{array}$ & 680 & 50 & 730 & 93.15 & $1.86 \times 10^{6}$ \\
\hline $\begin{array}{c}\text { Cells + } \\
\text { Yellow } \\
\text { Pigment }\end{array}$ & 700 & 40 & 740 & 94.59 & $1.89 \times 10^{6}$ \\
\hline $\begin{array}{c}\text { Cells + Pink } \\
\text { red Pigment }\end{array}$ & 625 & 48 & 673 & 92.86 & $1.85 \times 10^{6}$ \\
\hline
\end{tabular}

Table.4 Antimicrobial activity of obtained pigments against Human Pathogens

\begin{tabular}{|c|c|c|c|c|c|}
\hline $\begin{array}{c}\text { Sr. } \\
\text { No }\end{array}$ & $\begin{array}{c}\text { Human } \\
\text { Pathogen } \\
\text { Pseudomonas } \\
\text { aeruginosa }\end{array}$ & $\begin{array}{c}\text { Blue } \\
\text { Pigment }\end{array}$ & $\begin{array}{c}\text { Y e I l o w } \\
\text { Pigment }\end{array}$ & $\begin{array}{c}\text { O r a n g e } \\
\text { Pigment }\end{array}$ & $\begin{array}{c}\text { Pink red } \\
\text { Pigment }\end{array}$ \\
\hline 1 & Negative & Positive & Negative \\
\hline 2 & E.coli & Negative & Negative & Negative & Negative \\
\hline 3 & $\begin{array}{c}\text { Staphylococcus } \\
\text { aureus }\end{array}$ & Positive & Negative & Negative & Positive \\
\hline
\end{tabular}

Table.5 Purification of obtained pigments

\begin{tabular}{|c|c|c|c|}
\hline Sr. No. & Pigments & $\begin{array}{c}\text { Amount purified } \\
\text { in Methanolic } \\
\text { extract } \\
\text { (gm/100ml) }\end{array}$ & $\begin{array}{c}\text { Amount purified in } \\
\text { Ethanolic extract } \\
\text { (gm/100ml) }\end{array}$ \\
\hline $\mathbf{1 .}$ & Blue & 0.34 & 0.68 \\
\hline $\mathbf{2 .}$ & Orange & 0.52 & 0.56 \\
\hline $\mathbf{3 .}$ & Magenta & 0.35 & 0.56 \\
\hline
\end{tabular}

Table.6 Rf values of pigments by using Thin Layer Chromatography

\begin{tabular}{|c|c|c|}
\hline Sr. No. & Pigments & Rf Value \\
\hline $\mathbf{1 .}$ & Blue & 0.59 \\
\hline $\mathbf{2 .}$ & Orange & 0.76 \\
\hline 3. & Magenta & 0.69 \\
\hline
\end{tabular}


Table.7 Functional Groups present in obtained pigments by using FTIR

\begin{tabular}{|c|c|c|}
\hline $\begin{array}{c}\text { Extracted } \\
\text { Pigment }\end{array}$ & $\begin{array}{c}\text { Peak } \\
\left(\mathbf{c m}^{-\mathbf{1}}\right)\end{array}$ & Functional Group \\
\hline \multirow{3}{*}{ Blue } & 1645.28 & Hydrocarbon double bond $(-\mathrm{C}=\mathrm{C}-)$ \\
\cline { 2 - 3 } & 2854.65 & Aldehyde group $(\mathrm{CHO})$ \\
\cline { 2 - 3 } & 2924.09 & Aliphatic saturated hydrocarbon chain \\
\cline { 2 - 3 } Orange & 3315.63 & Hydroxyl group $(\mathrm{OH})$ \\
\hline \multirow{5}{*}{ Pink red } & 1045.42 & Alkyl group $(\mathrm{CH})$ \\
\cline { 2 - 3 } & 1633.71 & Alkene group $(-\mathrm{C}=\mathrm{C}-)$ \\
\cline { 2 - 3 } & 2856.58 & Methyl group $(\mathrm{CH})$ \\
\hline & 3273.20 & Hydroxyl group $(\mathrm{OH})$ \\
\hline & 1409.96 & Alkene group $(-\mathrm{C}=\mathrm{C}-)$ \\
\cline { 2 - 3 } & 1606.70 & Ketonic group $(\mathrm{C}=\mathrm{O})$ \\
\cline { 2 - 3 } & 2924.09 & Aliphatic saturated hydrocarbon chain \\
\cline { 2 - 3 } & 3323.35 & Hydroxyl group $(\mathrm{OH})$ \\
\hline
\end{tabular}

\section{Spectrophotometric Analysis of Pigments}

Fig.1 Maximum absorbance of blue pigment obtained at $450 \mathrm{~nm}$

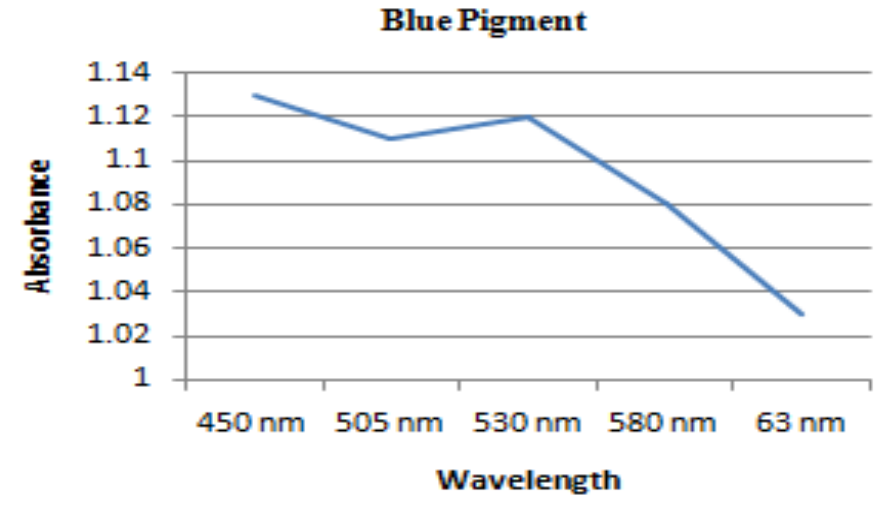

Fig.2 Maximum absorbance of orange pigment obtained at $530 \mathrm{~nm}$

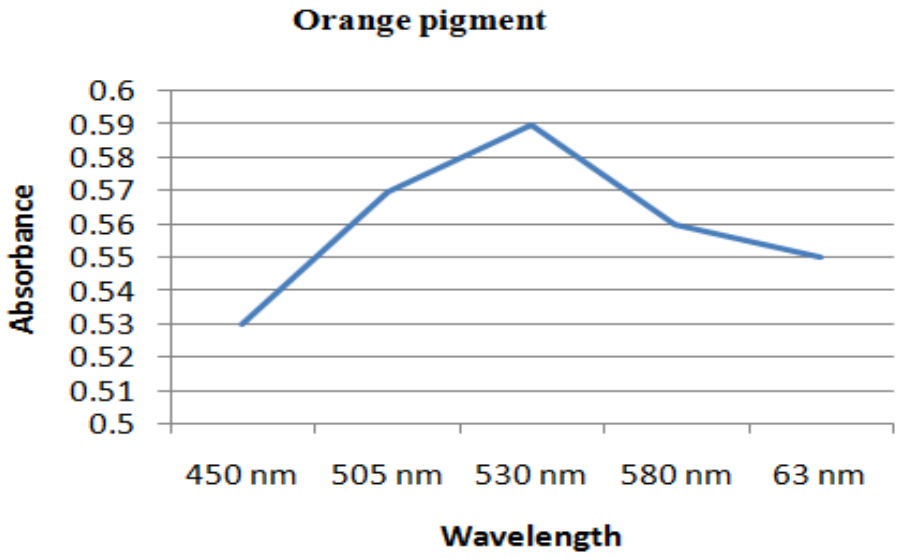


Fig.3 Maximum absorbance of yellow pigment obtained at $530 \mathrm{~nm}$ Yellow pigment

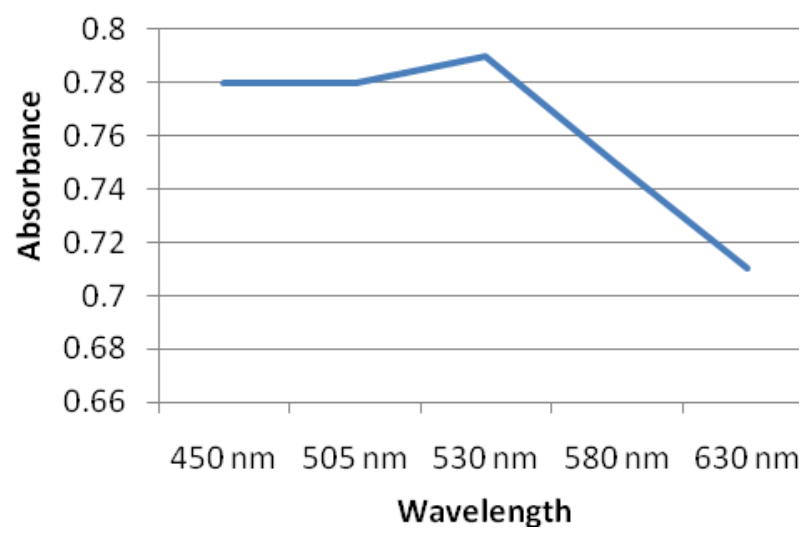

Fig.4 Maximum absorbance of pink red pigment obtained at $505 \mathrm{~nm}$

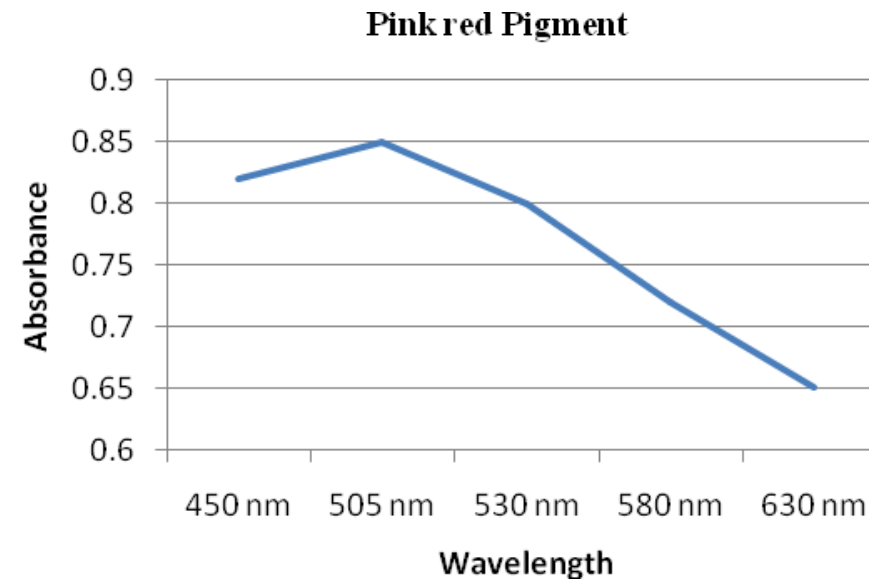

\section{FTIR (Fourier Transform Infra-Red Spectroscopy)}

1. Blue Pigment

Fig.5 FTIR Analysis of Blue Colored Pigment

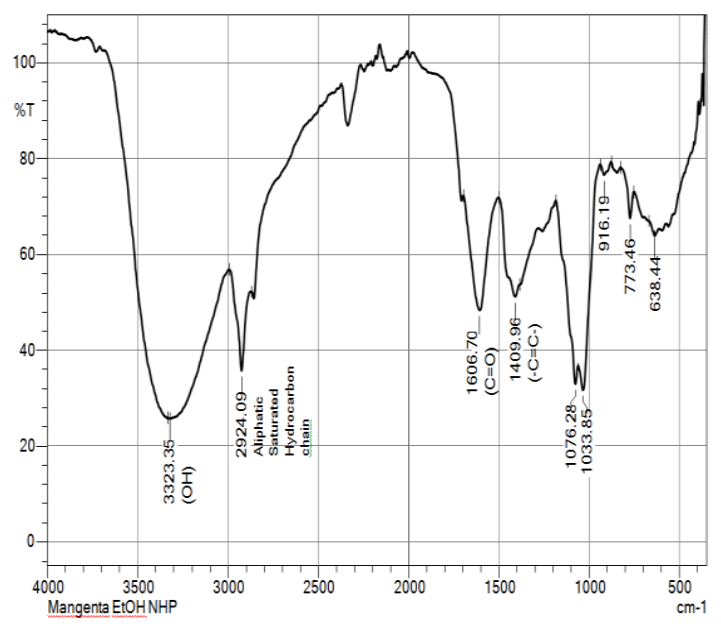




\section{Orange Pigment}

Fig.6 FTIR Analysis of Orange Colored Pigment

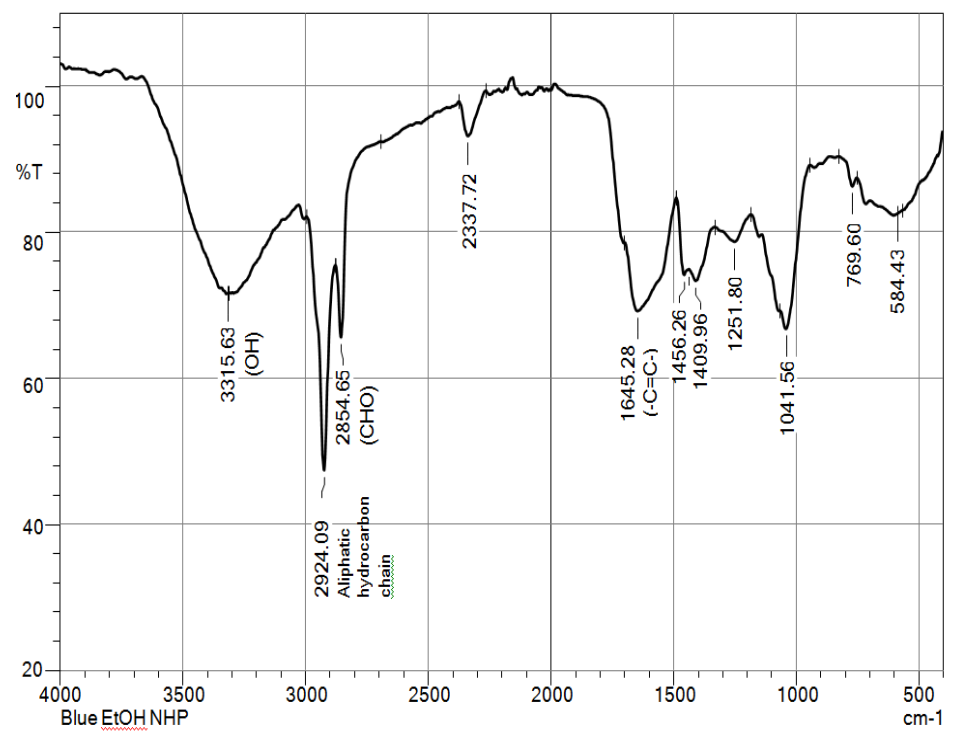

3. Pink red Pigment

Fig.7 FTIR Analysis of Pink Colored Pigment

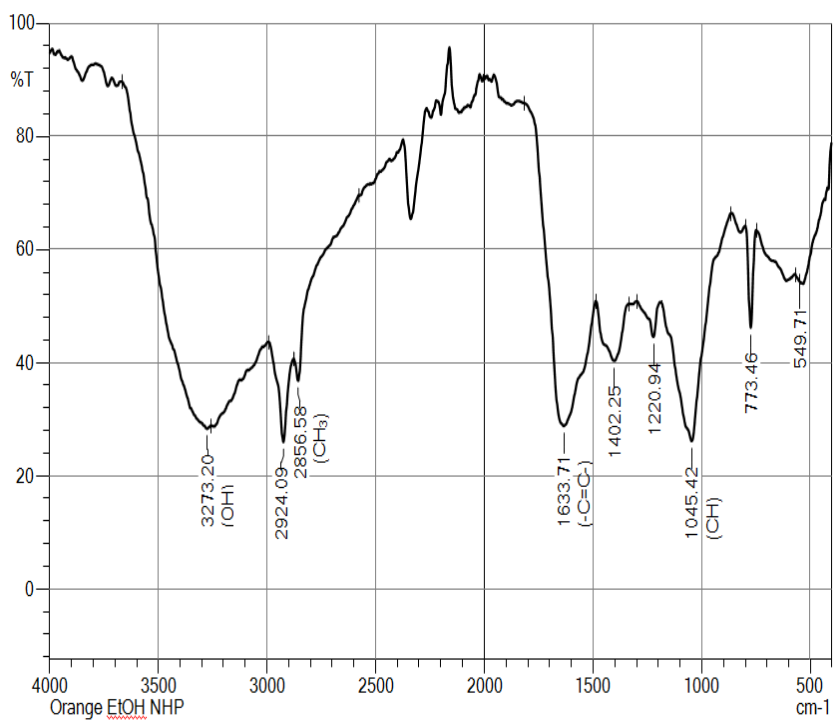

The extracted pigments were characterized by pigment were identified.

FTIR for the conformation of functional groups. The functional groups of pigments were analyzed on the basis of obtained peaks. They are as follows:

Functional groups of original pigments and obtained pigments were compared. After comparison pigments were confirmed as pyocyanin, asthaxanthin, zeaxanthin and

FTIR was performed. According to FTIR, canthaxanthin.

functional groups present in an obtained 


\section{Applications}

\section{Applications in Textile industry}

Cotton balls were colored with Blue, Orange, Yellow, Pink-red pigments (Rajendra R, et al., 2014)

Thread bundles were colored with Blue, Orange, Yellow, Pink-red pigments

Pieces of cloth were colored with Blue, Orange, Yellow and Pink-red Pigments

\section{Applications in Paper industry}

Pieces of paper were colored with Blue, Orange, Yellow and Pink red pigments

\section{Applications in cosmetic industry}

Nail paint was colored with extracted Pink-red color pigment.

Lip care was colored with extracted Orange color pigment.

\section{Applications in Other industries}

Candles were colored with Pink-red and Orange colored pigment.

Hair rubber and Hair belt were colored with pink-red, Orange, Yellow and Blue Pigments.

Pigments are the compounds which are intensely colored and use to color other many materials. Biochemical identification gave results that blue color (Pyocyanin) pigment might be given by an organism Pseudomonas aeruginosa, Orange color (Asthaxanthin) pigment might be given by an organism Brevibacterium linens, Yellow color (Zeaxanthin) pigment might be given by an organism Paracoccus zeaxanthifaciens, and Pink-red color (Canthaxanthin) pigment might be given by an organism Monascusroseus according to bergey's manual. The extraction of pigments was best in ethanol. TLC was carried out and single spot was analyzed through it. TLC analysis reveals that the pigments were purified. FTIR analysis was performed for the purification and structural analysis because of which different bonds and functional groups present in the pigmented compounds were studied. Rice powder extract gave good results for extraction of pigments. Cell viability was observed more than $90 \%$ which is safe for the eukaryotic system. Probiotic test gave positive results for Orange and Pink-red pigment, thus, these cannot be used as a food colorant but these pigments can be used in Textile, Paper, Cosmetic and in other industries. Blue and Yellow color pigment shows negative probiotic test. Thus, these pigments can be used in Textile, Paper, Cosmetic and in other industries along with food industry. It is concluded that, the naturally occurring microbial pigments are safer than that of the synthetic colors.

\section{Acknowledgement}

The authors wish to express their unreserved gratitude to respected Dr. V. B. Gaikwad, Principal of K. R. T. Arts, B. H. Commerce, A.M. Science College (KTHM College) and Prof. Smt. S. N. Patil, Head, Department of Biotechnology, KTHM College, Nashik, Maharashtra, India for granting the permission and providing all laboratory facilities during research work. They would also like to Thank to KTHM College, for providing the FTIR Analysis Facilities required for Functional Group Identification.

\section{References}

Bhat M. R, Marar T, Media Optimization, Extraction and Partial Characterization of an Orange Pigment from Salinicoccus sp. $\quad$ MKJ 99775.International journal of Life Sciences Biotechnology and Pharma Research Vol.4,No.2,April 2015. 
Bhat S. V, Khan S. S et al., Isolation and Characterization of Pigment Producing Bacteria from Various food. International Journal of Applied Research. Vol4,Issue 10:16051609, October 2013.

Divya Jose, A. Mohandas and J. S. Bright Singh, A Non-pathogenic Environmental Isolate of Pseudomonas aeruginosa MCCB 123 with Biotechnological Potential, National Center for Aquatic Animal Health, Cochin University of Science and Technology, Cochin, India, 2018.

Francielo Vendruscolo, Rose Marie Meinicke Buhler, Julio Cesar de Carvalho, Debora de Oliveira, Denise Estevez Moritz, Willibaldo Schimidell, Jorge LuizNinow, Monascus: a Reality on the Production and Application Of Microbial pigments, Journal of Application of Biotechnology and Biochemistry, October 2015.

Goswami B and Bhowal J, Identification and Characterization of Extracellular Red pigment producing bacteria isolated from soil, International journal of Current Microbiology and Applied Sciences. Vol 3,Issue 9:169-176,2014.

Hizbullahi M U, Nafiu A et al., Bacterial pigments and its Significance. Microbiology department Sokoto state university, Vol 4,Issue 3,2017.

Levine s, Stevenson et al., Infrared spectrophotometry of Enteric bacteria. J. Bacterial. Issue 65:10-15,1953.

Meenakshi, Neeraj Rama, Anjali Chauhan, microbes and Pigments, Journal of Pharmacognosy and Phytochemistry, University of Horticulture and Forestry, Nauni(Solan), Himachal Pradesh, India, December 2017.

Navinraju, V. and T. Radha, Production of Extracellular Pigment of Microbes and its Applications. International Journal on Applied Bioengineering, Vol9, Issue
2,July 2015.

Numann D, Helm D et al., The characterization of Microorganism by Fourier Transform Infrared Spectroscopy Modern Techniques of Rapid Microbiological Analysis, NY 43-96,1991.

Rajendran R, Selvi B.T., Natural dyeing of Cotton fabrics with pigment extracted from Roseomonasfauriae. Universal Journal of Environmental Research and Technology. Vol.4, Issue 1:5459,2014 .

Samyuktha, S. and Sayali Naphade Mahajan, Isolation and Identification of Pigment Producing Bacteria and Characterization of Extracted Pigments, International Journal of Applied Research 2016.

Sebnem G and Gozen A. C. et al., Use of Fourier Transform Infrared Spectroscopy for Rapid Comparative analysis of Bacillus and Micrococcus Isolates. Applied and Environmental Biology, 1301-1307,2008.

Sinha S, Choubey $\mathrm{S}$ et al., Identification, Characterization of Pigment Producing Bacterial From Soil and Water. International Journal of Pharmaceutical Science, Rev. Res., Vol 42,Issue (2) 119-124,JanuaryFebruary,2017.

Suryawanshi T, Nair V, et al., Isolation of pigmented bacteria for various applications. Vol.7, Issue 1,January2017.

Tarangini Korumilli, Studies on Pigment Productiom by Microorganisms Using Raw Materials of Agro-industrial Origin, National institute of Technology, Oissa, India, June-2014.

Trypan blue exclusion test for cell viability Ariffin et al., 2010; Hadzir et al., 2014; Shahrul Hisham et al., 2016; Strober 2001).

Venil C. K, Zakaria Z. A, Bacterial Pigments 
and their applications. Vol.48,Issue 7,July 2013.

Vora J. U, Jain N. K and Modi H. A, Extraction, Characterization and Application studies of red pigmentof halophile. Int. J. Pure App. Biosci. 2(6):160-168 2014.

Vora J. U, Jain N. K and Modi H. A., Identification and Characterization of
Pigment Producing strain, International journal of Current Microbiology and Applied Sciences, Vol.4, Issues9:850$859,2015$.

Zerrad A, Annissi $\mathrm{J}$ et al., Antioxidant and Antimicrobial Activities of Melanin, Journal of Biotechnology Letters. Vol.5, Issue 1:087-094, 2014.

\section{How to cite this article:}

Hrucha Vaidya, Nishigandha Upasani and Padmini S. Wagh. 2021. Microbial Pigments: Natural Colorants and their Industrial Applications. Int.J.Curr.Microbiol.App.Sci. 10(05): 631645. doi: https://doi.org/10.20546/ijcmas.2021.1005.071 